\title{
A comparative anatomy of the lingual apparatus of Indian doves (genus: Streptopelia and Stigmatopelia), Aves: Columbidae
}

\author{
Varsha Trivedi
}

\begin{abstract}
Background: The structure of the lingua of birds frequently gives some clue to the principal diet and manner of feeding of the species. The lingua is suitably modified for this purpose or does not intent the present work to understand it. The anatomical details of the lingual apparatus and their associated epidermal, musculature, and osteological elements of Indian doves (Aves: Columbidae) Eurasian collared dove (Streptopelia decaocto) and laughing dove (Stigmatopelia senegalensis) with comparison are lacking in the literature.

Results: A total of eight ( $n=8 /$ species) freshly preserved adult specimens with natural mortalities from Central Saurashtra, Western India, were examined. All the morphological features of species were observed in living as well as in preserved with the help of a pair of binoculars in the field and in the laboratory with stereo zoom dissecting microscope and camera lucida which are used for illustrations. The anatomical study includes the epidermal structures of the buccal region, lingua, apparatus hyobranchialis, and lingual muscles in relation to feeding behaviors and food. All these aspects are correlated with the food habits and finally with the muscles which bring about the suitable movements of the lingua.

Conclusion: The lingua in Eurasian collared dove (Streptopelia decaocto) and laughing dove (Stigmatopelia senegalensis) studied here does not exhibit any wide variations in appearance as such. Although the comparison between the two dove species is reflected, a relation in diverse food habits and all the morphological variables do not reflect allometric consequences of selection on body size. Finally, the assumption appears intuitively right between morphology, food habits, and variable size of the food items and clears various microhabitat choices in adverse conditions.
\end{abstract}

Keywords: Indian dove, Lingual apparatus, Epidermal, Skeleton, Musculature, Eco-morphology

\section{Background}

The role played by the lingua in the manipulation and transportation of food in birds is well known and involves a variety of movements of the lingua. The variations in the mode of operation of the lingua in birds depend upon their food, feeding behavior, and the nature of the structural adaptations in the lingua, its epidermal structures, and the

Correspondence: vtrivedi_2@rediffmail.com

Laboratory of Animal Ecology and Wildlife Biology, Department of

Biosciences-UGC Center of Advanced Studies, Saurashtra University, Rajkot 360005, Gujarat, India

Springer Open apparatus hyobranchialis which forms the skeleton of the lingua, and lingual myology. While a number of workers in the past, notable amongst them being Mudge (1903), Gardener (1926), Engel (1938), Weymouth et al. (1964), McLelland (1968), Bock (1972, 1978), Lucas and Stettenheim (1972), Morioka (1974), Zweers (1974, 1982a, 1982b), Homberger and Meyers (1989), and Shawki and Al-Jalaud (1994); latest by Jackowiak and Godynicki (2005), Jackowiak and Ludwig (2008), Tivane et al. (2011), Venkatesan et al. (2015), Shawki et al. (2016), Fatma (2017), and Mahmoud et al. (2018) have studied the various aspect of lingual 
morphology. The studies on the functional anatomy of feeding apparatus conducted in several Indian birds by Dubale and Rawal (1966), Dubale and Thomas (1978), Rawal (1966, 1970), Soni (1976), Bhattacharyya (1994), Shukla (1999), Yumnam (2005), Trivedi (2012), and Trivedi and Soni (2013). A detail phenotype variables on functional anatomy of the musculature of lingual apparatus of Indian birds-genera Streptopelia and Stigmatopelia are not available; although DNA sequence analysis (Johnson et al., 2001) of selected two dove species clears that both differ, earlier laughing dove was put under genus Streptopelia (Ali and Ripley 1983). The present paper dealt with morphotomical structures of lingua and its epidermal investments, the structure of apparatus hyobranchialis, and mandible and lingual musculature in two dove birds namely Eurasian collared dove-Streptopelia decaocto and laughing doveStigmatopelia senegalensis (Grimmett et al. 2014). The food and feeding habits of selected dove species are diverse in many ways. An attempt has been made to correlate anatomical findings with food and feeding habits in nature.

\section{Materials and methods Morphology}

Eight adult birds were obtained from natural mortalities of urban, rural, and forest areas of Central Saurashtra of Western India (Table 1). Freshly died birds were preserved in $10 \%$ neutral formalin solution (Goodman and Fisher, 1962). Morphology of components of lingual apparatus, i.e., epidermal structures of the lower jaw and lingua, apparatus hyobranchialis, and details in the lingual muscles were studied under stereo zoom binocular dissecting microscope using the camera lucida and photographs (DSC- W7, digital still camera, Sony) along with binocular stereo zoom microscope (DV4, Carl Zeiss, German) with eyepieces of $\times 10$ both and objectives of $\times 8, \times 10, \times 12$, $\times 16, \times 20, \times 25$, and $\times 32$ for drawings and then reduced as per paper size using Photoshop software.

For osteological studies, the head of preserved specimens were dissected removing as many muscles as possible, and the remaining muscles were dissolved by placing in 5\% $\mathrm{KOH}$ solution for a day. Every care was taken to see that the skeletal elements remain articulated, washed under tap water, and then immersed under 30\% hydrogen peroxide solution for bleaching. The skeletal elements were washed again and later dried in an air oven.

The distribution of cartilage region in the apparatus hyobranchialis has been investigated by bulk staining with methylene blue and is indicated by stippling. The entire cartilaginous regions are indicated by dense and uniform stippling (i.e., large dots), and lighter stippling (i.e., less dots) indicates the intensity of blue staining of ossified regions (Fig. 2A, B).

\section{Morphometrical data}

The dimensions of the selected elements of lingual apparatus, i.e., size of the lingua, bony element apparatus hyobranchialis, and lingual muscles, were taken using digital caliper and divider under stereo zoom dissecting microscope. Measurements of bony elements (Table 3) are followed as per Soni (1976). The average length (mm), width $(\mathrm{mm})$, and mass (mg) of some muscles (Appendix 1) were taken for both doves and comparison of fiber patterns, origin, and insertion of lingual muscles are shown in Appendix 2.

For the weight, the dissected muscles were kept into 95\% alcohol for 2 weeks (Goodman and Fisher 1962) and then pressed and dried with filter papers, immediately weighed to ten thousandth of a gram on electrically operated automatic single pan balance (Sartorius). The actions of the superficial to the deeper muscles are studied by pulling them in the direction of their origin-insertion axis.

In the text, letter "M." is used for the muscle and "Mm." is used for a series of muscles whereas "Os" for the Osteologia or bone and "N." is for the nerve. The muscles are described from superficial to deeper layers, starting from a ventral view. All abbreviations used are explained separately.

Anatomical nomenclature follows that of the Nomina Anatomica Avium (Baumel et al. 1979, 1993).

Table 1 Specimen code (birds) and measurements of the adult specimens (before dissection) with sex status (after dissection) are selected for the study (order: Columbiformes, family: Columbidae)

\begin{tabular}{|c|c|c|c|c|c|c|}
\hline Species/measurements (mid line mean value in $\mathrm{mm}$ ) & Specimen & Code no. & Length of bill & Length of the skull & Total leg length & Total \\
\hline \multirow[t]{4}{*}{ Eurasian collared dove (Streptopelia decaocto) } & 1 & UM1 & 17.0 & 38.0 & 131 & \multirow[t]{2}{*}{$2 \mathrm{M}$} \\
\hline & 2 & SM2 & 21.0 & 48.0 & 132 & \\
\hline & 3 & UF1 & 22.0 & 48.0 & 132 & \multirow[t]{2}{*}{$2 \mathrm{~F}$} \\
\hline & 4 & RF2 & 21.0 & 47.0 & 124.5 & \\
\hline \multirow[t]{4}{*}{ Laughing dove (Stigmatopelia senegalensis) } & 5 & RM1 & 18.5 & 39.5 & 112 & \multirow[t]{2}{*}{$2 \mathrm{M}$} \\
\hline & 6 & UM2 & 18.0 & 38.5 & 110 & \\
\hline & 7 & UF1 & 20.0 & 47.0 & 114 & \multirow[t]{2}{*}{$2 \mathrm{~F}$} \\
\hline & 8 & UF2 & 17.0 & 38.0 & 107.5 & \\
\hline
\end{tabular}

$U$ are for urban, $R$ for rural, and $S$ for Sasan Gir Forest sampling code of male $(M)$ and female $(F)$ specimens obtained from Central Saurashtra (specimens code is given on occurrence and sex base) 


\section{Diversity of food and food habits}

Apart from using information available in the literature, the food habits of birds selected for the study have been observed in nature as well as in captivities. Several food items were recorded through gut examination of Eurasian collared dove (Streptopelia decaocto) and laughing dove (Stigmatopelia senegalensis) by Trivedi (2012) and Trivedi and Soni (2013). It is assumed that morphological differences between two species determine their foraging efficiencies in various microhabitats.

\section{Results}

\section{Morphology and morphometrical data}

The anatomy of epidermal structures of the lingua, lingual muscles, and their bony elements are described for Eurasian collared dove (Streptopelia decaocto), and remarkable variations found in those of the laughing dove (Stigmatopelia senegalensis) are compared (morphological description studied in all specimens).

\section{Epidermal structure of the lingua and buccal region (Fig.}

\section{A, Table 2)}

The lingua is long (ranges from 9 to $11.5 \mathrm{~mm}$ ), lanceolate, hard, concave, and free end which extends up to the base of the pars symphysialis. The tip of the lingua is long and pointed, narrow cranially, broad caudally (ranges from 3.5 to $4 \mathrm{~mm}$ ), concave dorsally, and slimy. The caudal corner of the lingua bordered by two long, thick backwardly directed lateral muscular smooth spines, and 9 to 12 small $\mathrm{V}$ shaped central spines is the papillae linguales. The gap between the lingua and glottis is a long, wide, soft, elevated fleshy surface which provides numerous various size orderly arranged taste pits. The 6-mm-long and 3-mm-wide ovalshaped glottis is bordered by a pair of thick, high triangleshaped lateral pads which are the mons-laryngealis that provide fine to large numerous taste pits. The caudal margin of the mons-laryngealis bears smooth backwardly directed lateral papillae. The triangular caudal part and large lateral side of the mons-laryngealis that comprise a number of non-keratinized enfolding are the frenulum linguae. The ventral surface of the lingua is covered by $\mathrm{M}$. genioglossus.

\section{Comparison (Fig. 1B, Table 2)}

In Stigmatopelia senegalensis (S. senegalensis), little differences are found. The lingua is a little short (ranges from 8 to $11.5 \mathrm{~mm}$ ); the tip of the lingua is also pointed, cranially narrow, hard, and $2.5 \mathrm{~mm}$ broad caudally; and the caudal margin also has two long, thick backwardly directed lateral muscular smooth papillae linguales but less in numbers with 6 to 7 small central spines. The area between the lingua and glottis is comparatively smaller, wide, and elevated soft surface and bears more or less of small uniform size and few scattered taste pits. The lateral of the glottis triangle mons-laryngealis has fewer taste pits, and their distribution pattern is differing; its caudal margins are also backwardly directed smooth lateral papillae. The folded frenulum linguae form a broad base caudally.

Table 2 shows that the proportions of the lingua are almost greater in Eurasian collared dove than the laughing dove. Moreover, this reflects the size of the lingua in rural and forest specimens is greater than the urban specimens in Eurasian collared dove.

\section{Osteology}

Apparatus hyobranchialis (Fig. 2A, Table 3)

The apparatus hyobranchialis acts as a spring board of various lingual muscles and muscles of the buccal floor. It forms the skeleton of the lingua and extends from the tip of the lingua to the cranial neck region. It curves around the caudolateral surface of the cranium. It is fairly variable in structure and size of its elements in both doves and consists of a median part formed by 3-4 skeletal elements and a pair of cornua. The Os entoglossum and Os basibranchiale rostrale et caudale form the medial part whereas Os ceratobranchiale and Os epibranchiale form the cornuae of the apparatus hyobranchialis.

\section{Os entoglossum (eg)}

The Os entoglossum is a 7-mm-long, narrow cranially, more or less dorso-ventrally flattened cartilaginous, and partly bony structure. Its caudal margin that is projected laterally is the cornua (2.5-mm long) of entoglossum, which directed backwardly. Between these two cornuae, a groove is present and Os entoglossum articulates with the bony Os basibranchiale rostrale; laterally, this bone is thin and slightly curved, dorsally facing concave surface, and deep concave in its caudal half (Fig. 2A). This concave bony base is deep and bordered by two sharp flanges (cornua), just anterior to the bony Os basibranchiale rostrale. This provides an attachment of M. hypoglossus obliquus. The Os entoglossum serves for the attachment of the various lingual muscles.

\section{Os basibranchiale rostrale (bbr)}

The Os basibranchiale rostrale is a 3-mm long, hard rod-like bony structure, narrow cranially, and broad caudally. Its dorsal surface bears a distinct median ridge. Cranially, it articulates with the bony base of Os entoglossum and caudally with the bony Os basibranchiale caudale and caudolateral with Os ceratobranchiale.

\section{Os basibranchiale caudale (bbc)}

The Os basibranchiale caudale is a 6 - $\mathrm{mm}$ long, bony ( 5 $\mathrm{mm})$, and cartilaginous rod-like structure $(1 \mathrm{~mm})$. The caudal tip is blunt and cartilaginous. Cranially, it is articulated by cartilaginous with the Os basibranchiale rostrale. 


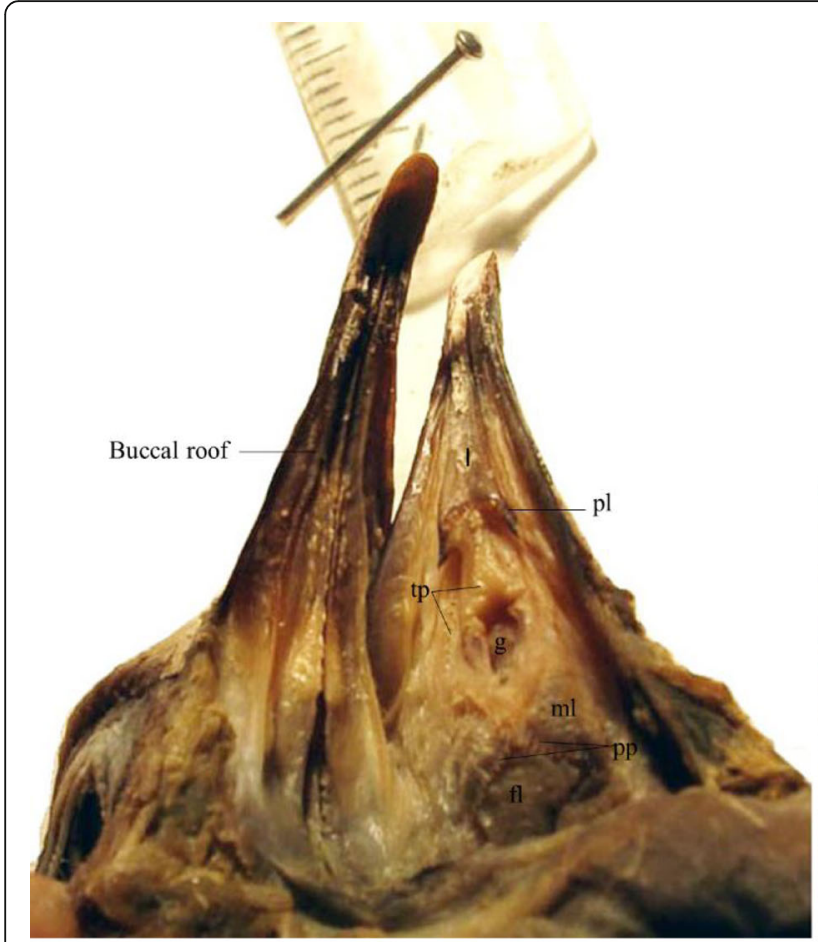

A. Streptopelia decaocto (RF2)

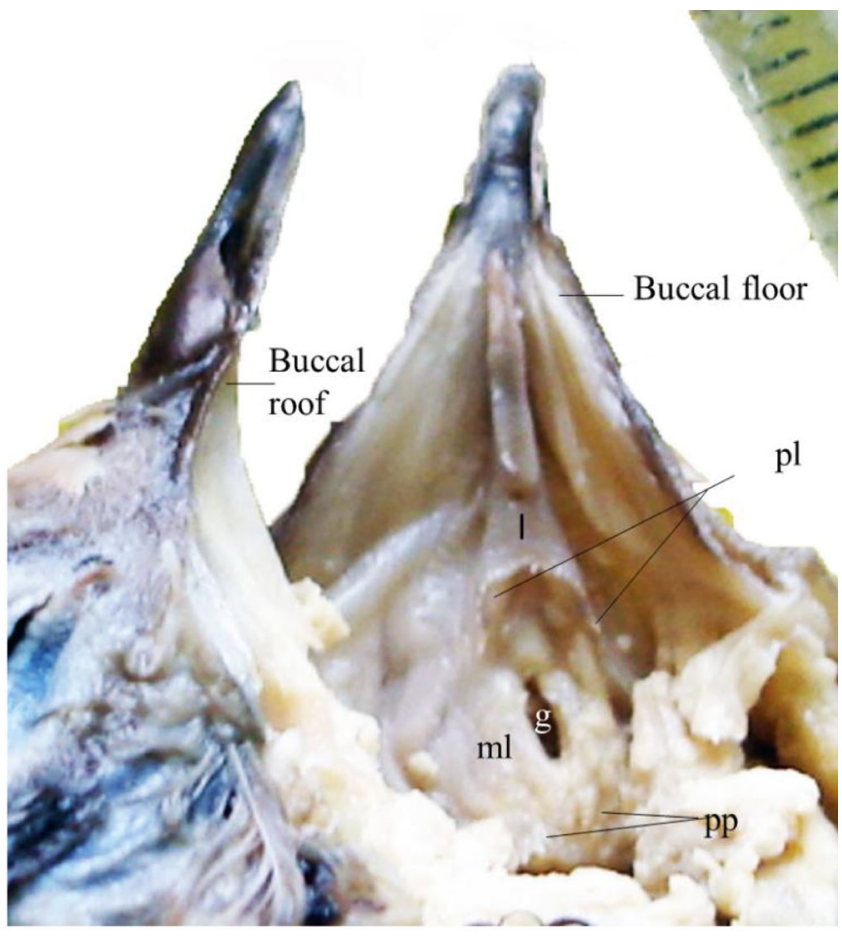

B. Stigmatopelia senegalensis (UF2)

Photographs of the inner view of buccal cavity (preserved specimens).

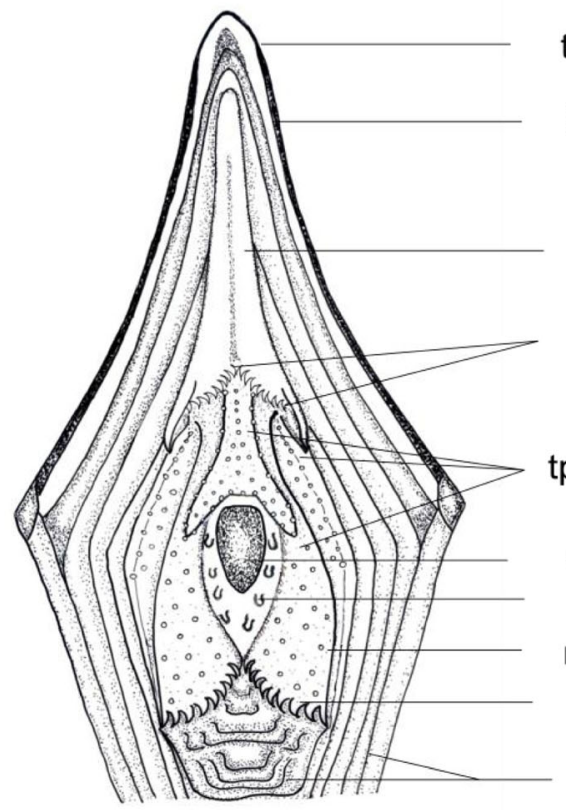

$5 \mathrm{~mm}$

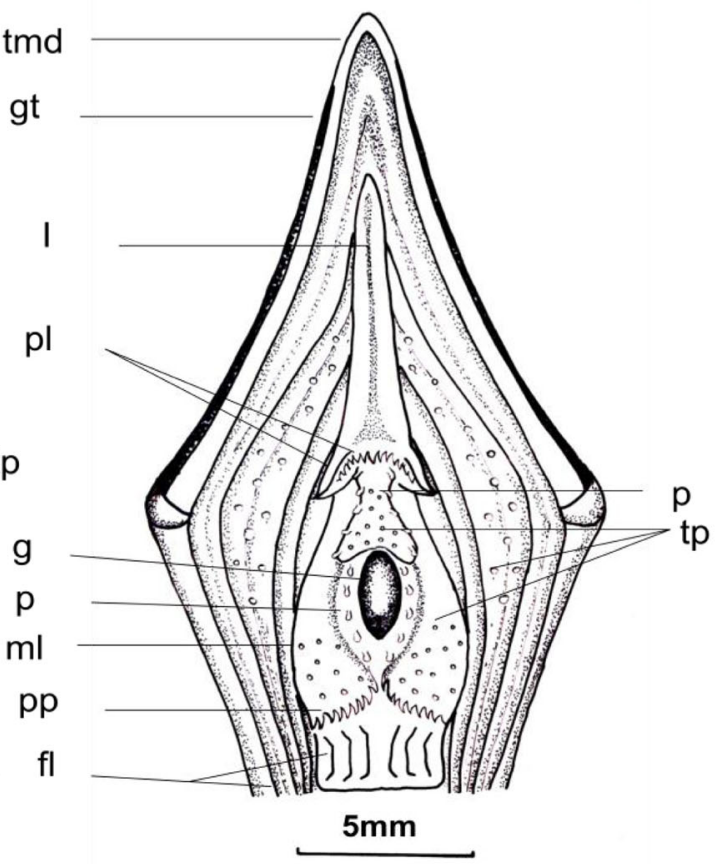

B

Fig. 1 The lingua along with the lower jaw showing epidermal structures of $\mathbf{A}$ Eurasian collared dove (Streptopelia decaocto)—RF2. B Laughing dove (Stigmatopelia senegalensis) —UF2. Abbreviations: fl, frenulum linguae; g, glottis; gt, gnathotheca; l, lingua; ml, mons laryngealis; pl, papillae linguals; pp, papillae pharyngeales; tmd, tomium mandibulare; tp, taste pits (line drawing using camera lucida) 
Table 2 Measurement $(\mathrm{mm})$ of the Lingua

\begin{tabular}{lllll}
\hline Birds & $\begin{array}{l}\text { No. of } \\
\text { specimens }\end{array}$ & $\begin{array}{l}\text { Sex status of } \\
\text { specimens }\end{array}$ & Length & Width \\
\hline Eurasian collared dove & 1 & UM1 & 9 & 3.5 \\
(Streptopelia decaocto) & 1 & SM2 & 11.5 & 4 \\
& 1 & UF1 & 10.5 & 4 \\
& 1 & RF2 & 11.5 & 4 \\
& $n=4$ & Mean \pm SD & 10.63 & $3.88 \pm$ \\
& & & \pm 1.18 & 0.25 \\
Laughing dove & 1 & RM1 & 10.5 & 3.5 \\
(Stigmatopelia & 1 & UM2 & 9.5 & 3.5 \\
senegalensis) & 1 & UF1 & 11.5 & 2.5 \\
& 1 & UF2 & 8 & 3 \\
& $n=4$ & Mean \pm SD & $9.88 \pm$ & $3.13 \pm$ \\
& & & 1.49 & 0.48 \\
\hline
\end{tabular}

$\mathrm{U}$ are for urban, $\mathrm{R}$ for rural, and $\mathrm{S}$ for Sasan forest samplings

\section{Os ceratobranchiale $(\mathrm{cb})$}

These are the longest $(13 \mathrm{~mm})$ among all bony elements of the apparatus hyobranchialis. It articulates with the Os basibranchiale rostrale cranially and with Os epibranchiale I caudally. Its dorsal surface has shallow groove which provides an attachment for various jaw muscles. This bony element retains slightly cartilaginous at both ends (Fig. 2A).

\section{Os epibranchiale I (eb I)}

The Os epibranchiale I is a 7-mm-long bony structure lying between the Os ceratobranchiale and epibranchiale II. Its dorso-medial side shallow groove provides an attachment for the jaw muscles, cranially broad, and narrow caudally.

\section{Os epibranchiale II (eb II)}

The Os epibranchiale II is a 4-mm-long thin cartilaginous structure lying caudally to the Os epibranchiale I.

\section{Comparison (Fig. 2B, Table 3)}

The apparatus hyobranchialis is having both bony as well as more cartilaginous elements, fairly less strong, and longer. The Os epibranchiale II is a little longer $(5.5 \mathrm{~mm})$ than the Eurasian collared dove and very thin cartilaginous. A 6.5-mm-long Os entoglossum is dorso-ventrally flattened. Comparatively, less concave bony base at the middle region extended towards the rostral of Os entoglossum. The rodlike bony element of Os basibranchiale rostrale is triangular and cartilaginous at their articulation with the Os entoglossum, and Os basibranchiale caudale is a little small ( $5 \mathrm{~mm})$, partly bony and cartilaginous. The Os ceratobranchiale is similar, i.e., 13-mm long rod-like bony elements and slightly cartilaginous at their articulation.

The dimension of bony elements of the apparatus hyobranchialis is summarized in Table 3 for comparisons.

\section{Myology of the lingua}

The muscles responsible for the functioning of the lingua are grouped as mandibular and apparatus hyobranchialis muscles (all specimens studied for each species and measurements consider for UF1 specimens of each species).

\section{Muscles associated with the lower jaw M. intermandibularis (Fig. 3A, Appendices 1 and 2)}

Most superficial muscle occupied the ventral side of the lower jaw. It extends between two halves of mandibular rami. These parallel fibered thin sheet bellies conceal M. genioglossus, M. intercerato-branchialis, M. serpihyoideus, and M. stylohyoideus. It is divided into two parts, i.e., ventralis and dorsalis and innervated by the $\mathrm{N}$. intermandibularis of the $\mathrm{N}$. trigeminalis.

(a) M. intermandibularis ventralis (M. iv, Fig. 3A, Appendices 1 and 2).

Very thin, triangular sheet-like, obliquely spread parallel fiber muscle, spreads over deep M. genioglossus, extends in between both rami of Os dentale, and lies just cranial to the $\mathrm{M}$. intermandibularis dorsalis. It is 2 to 4 $\mathrm{mm}$ long and it is narrow to broad, seems leaf-shaped, and the central belly is $17-\mathrm{mm}$ broad. It arises flashily from the inner surface of Os dentale; fibers run a little forward and inward position. It is flashily inserted to the mid-ventral line where it meets with its counterpart on the opposite side.

\section{Comparison (Appendices 1 and 2)}

No mark variation exception in size 2- to 3-mm long, and the central belly is $18-\mathrm{mm}$ broad. Fleshy fibers insert on the mid-ventral line (i.e., 17-mm broad).

(b) M. intermandibularis dorsalis (M. id, Fig. 3A, Appendices 1 and 2)

This is comparatively flashier and more compact sheet than the ventralis part. A 14-mm-long and 3-mm broad strap-like strong muscle conceals little ventralis part of this muscle. It lies superficial to the M. serpihyoideus and M. stylohyoideus. These can be divisible by location, i.e., caudal and cranial part. The flashy origin is from the lateral surface of Os articulare, cranial to the insertion of M. depressor mandibulae, and caudal to the insertion of M. Pterygoideus ventralis lateralis. The origin is narrower than the inserted region (i.e., 2 to $5-\mathrm{mm}$ broad). All the parallel fibers run forward and inward to insert upon the medial raphe, where it meets with its counterpart of the opposite side (i.e., 5-mm broad) just below to M. intermandibularis ventralis part.

Comparison (Appendices 1 and 2)

It is comparatively thin, small sheet, and its origin to insertion is likewise as $S$. decaocto. The entire belly is 12-mm-long and 2-mm broad and gets inserted by 4mm-wide flashy fibers.

\section{Action}



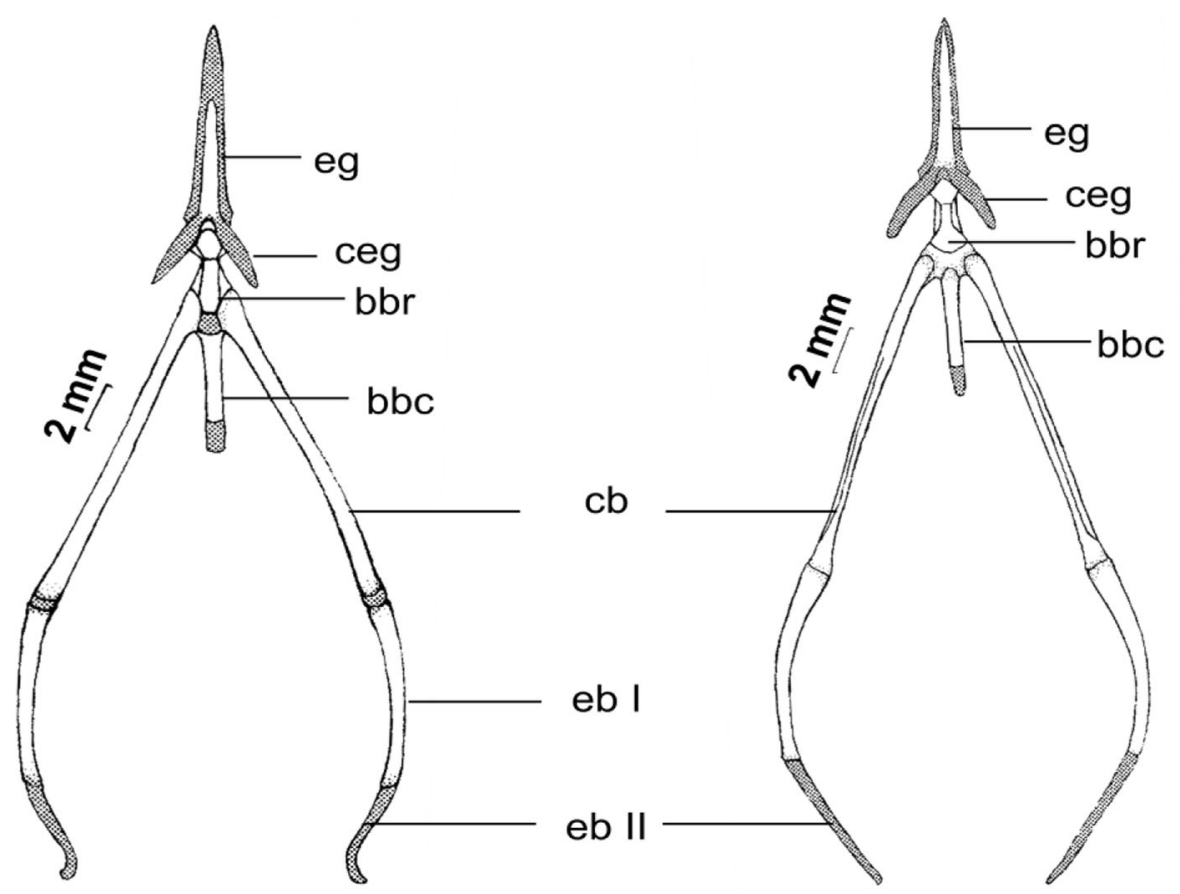

A

Dorsal View

B

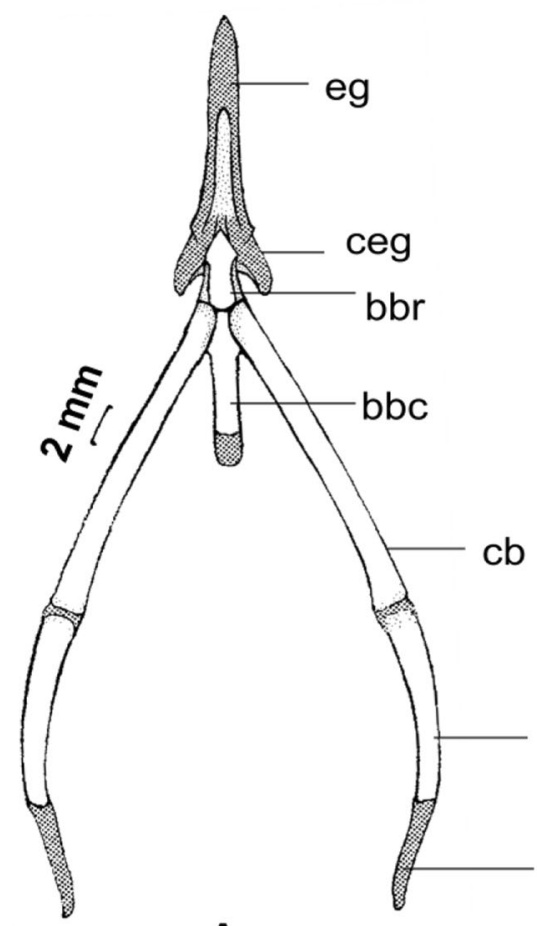

A

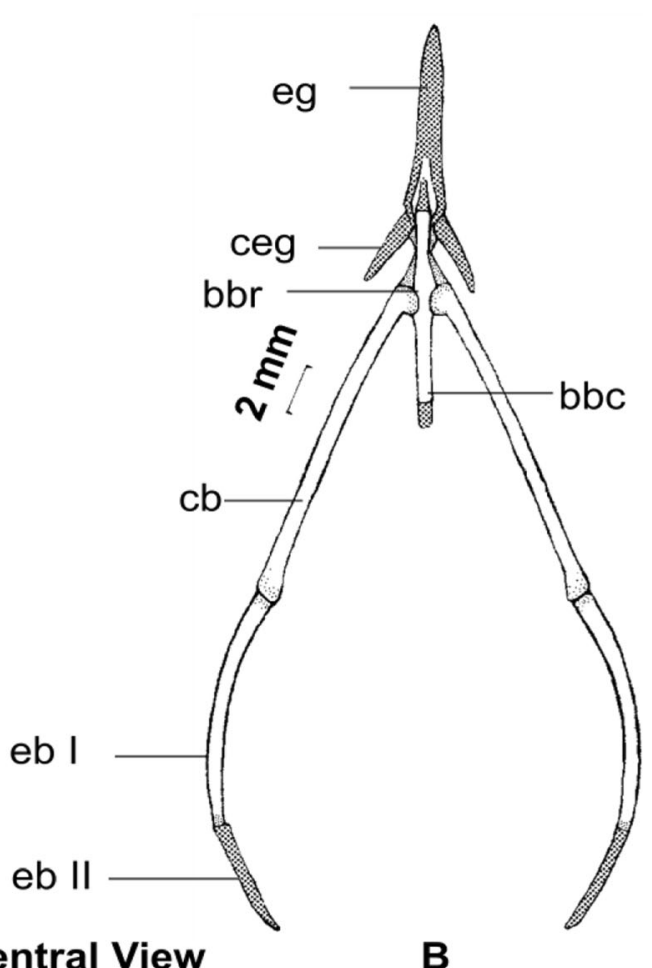

Fig. 2 Apparatus hyobranchialis of A Eurasian collared dove (Streptopelia decaocto-UF1). B Laughing dove (Stigmatopelia senegalensis—UF1) (line drawing using camera lucida). Abbreviations: bbc, Os basibranchiale caudale; bbr, Os basibranchiale rostrale; cb, Os ceratobranchiale; ceg, cornua of Os entoglossum; eb. I, Os epibranchiale I; eb. II, Os epibranchiale II; eg, Os entoglossum (Note: Cartilage distributions are indicated by stippling, and entirely cartilaginous regions are indicated by dense uniform stippling, lighter stippling in ossified regions.) 
Table 3 Dimension of bony elements of the apparatus hyobranchialis

\begin{tabular}{lll}
\hline $\begin{array}{l}\text { Name of measurements (mean } \\
\text { value of both side in mm) }\end{array}$ & $\begin{array}{l}\text { Eurasian collared } \\
\text { dove (UF1) }\end{array}$ & $\begin{array}{l}\text { Laughing } \\
\text { dove (UF1) }\end{array}$ \\
\hline $\begin{array}{l}\text { Length of Os entoglossum } \\
\text { Length of cornua of Os entoglossum }\end{array}$ & 7 & 6.5 \\
Length of Os basibranchiale rostrale & 3 & 3 \\
Length of Os basibranchiale caudale & 6 & 3.5 \\
Length of Os ceratobranchiale & 13 & 5 \\
Length of Os epibranchiale I & 7 & 13 \\
Length of Os epibranchiale II & 4 & 7.5 \\
Length from Os entoglossum to Os & 16 & 5.5 \\
basibranchiale caudale & & 16 \\
\hline
\end{tabular}

Both the parts are raising the floor of the buccal cavity by its contraction.

\section{Muscles associated with the mandibular and apparatus hyomandibularis}

M. stylohyoideus (M. styh, Fig. 3B, D, Appendices 1 and 2)

The M. stylohyoideus is a 12 to $13-\mathrm{mm}$-long parallel fiber belly situated below Mm. intermandibularis dorsalis et ventralis. This extends from caudo-ventral side of Os articulare to dorsolateral surface of the Os basibranchiale rostralis. One third of the belly from its origin is compressed dorso-ventrally and appears broad ribbon-like. Near its insertion, the belly becomes laterally compressed, narrow, and more flashy. Two millimeters of broad flashy fibers arise from ventro-lateral surface of the Os articulare caudal to the insertion of the $M$. Pterygoideus ventralis lateralis and cranial to the insertion of $\mathrm{M}$. depressor man-

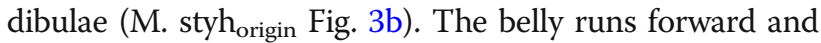
crosses downwards beneath tendinous origin of the $M$. ceratoglossus, and finally, flashy fibers get inserted on the Os basibranchiale rostralis below the M. hypoglossus obli-

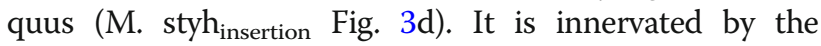
branch $\mathrm{N}$. hyomandibularis of the N. facialis.

Comparison (Appendix 1 and 2)

The origin to insertion is similar as Streptopelia decaocto, exceptionally in size.

\section{Action}

It raises the tongue when it bilaterally contracts by pulling it backward on the Os basibranchiale rostralis; thus, it also helps in the abduction of the lower jaw.

M. serpihyoideus (M. sph, Fig. 3A \& B, Appendix 1 and 2)

A long belly situated on the ventral side of the skull arises caudally from the neck region at the level of the M. branchiomandibularis and passes beneath the M. intermandibularis dorsalis which almost conceal the distal belly. The entire belly is connected by the fascia to the M. intermandibularis ventralis et dorsalis and to the M. cucullaris cervicis at the level of the neck region and passes over the $M$. branchio-mandibularis near its insertion; here, the belly is concealed by the M. cucullaris capitis. Dubale and Rawal (1966) agree this muscle as the M. gularis posterior part for C. livia.

All the parallel fibers are pinnate out flashily from the skin of the neck by the facia at level mid-ventral line of the M. cucullaris cervicis and from the M. branchiomandibularis at lateral near the Os epibranciale II where the M. cucullaris capitis passes superficially. All the fibers move forward and inward, and finally, it gains a $2-\mathrm{mm}$ broad fleshy insertion on the floor of the buccal cavity at level on the lower surface of the caudal extremity of the Os dentale and caudal to the origin of cranial head of the M. branchio-mandibularis, just beneath near the insertion of the $M$. intermandibularis ventralis and lateral to the M. genioglossus (M. $\mathrm{sph}_{\text {insertion }}$ Fig. $\left.3 \mathrm{~B}\right)$. It is innervated by a branch of the $\mathrm{N}$. facialis.

Comparison (Appendices 1 and 2)

It is comparatively very long, broad parallel fiber muscle pinnate out from the origin.

\section{Action}

This muscle serves as a depressor of the lower jaw.

M. genioglossus (M. g, Fig. 3B, Appendices 1 and 2)

M. genioglossus is a 13-mm-long and 3-mm broad flat conical shape belly extending from the pars symphysialis of the mandibulae, just lateral to the mid-ventral line to the Os entoglossum. It is concealed by the M. intermandibularis ventralis. Cranially, it runs parallel to the sublingual gland and backward towards the lingua. Dubale and Rawal (1966) described this muscle under the single muscle M. genioglossus et $M$. geniohyoideus for C. livia. Here, it is considered that the $M$. genioglossus due to whole sheet spread over the Os entoglossum.

It arises fleshly and fans out from the caudo-ventral side of the pars symphysialis of the mandibula lateral to the mid-ventral line. Thereafter, all the parallel fibers become narrow in the middle and broad at distal; finally, it inserts flashily on the dorso-lateral edge of caudal Os entoglossum just below to the insertion of the M. stylohyoideus. Some fibers insert flashily on the ventral and ventrolateral surface of cornuae of the Os entoglossum, ventral to the insertion of the M. ceratoglossus and M. hypoglossus rostralis. N. hypoglossus innervates this muscle.

Comparison (Appendix 1 and 2)

It is a very long and broad belly in comparison.

\section{Action}

This muscle belly serves for rising the lingua upward.

M. branchiomandibularis (M. bm, Fig. 3A-C, Appendices 1 and 2)

M. branchiomandibularis is a 23.5-mm-long and 5$\mathrm{mm}$ broad, strong, large band of the compact muscle; this entwine on the distal part of the Os ceratobranchiale and Os epibranchiale I. The entire parallel fibers 

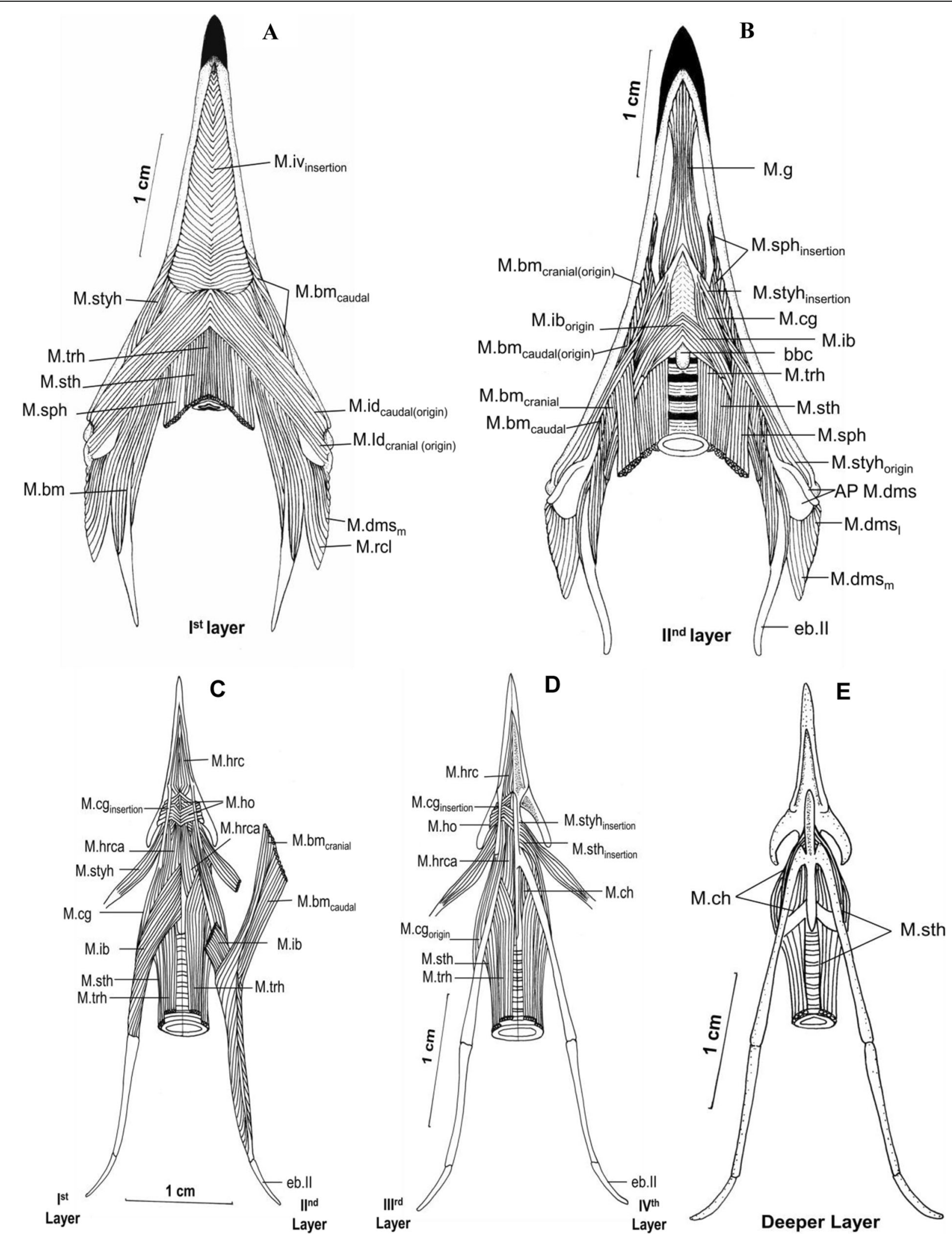

Fig. 3 (See legend on next page.) 
(See figure on previous page.)

Fig. 3 Ventral surface of the jaw showing the lingual muscles: Eurasian collared dove (S. decaocto-UF1). A Mandibular, hyoid, and anterior neck musculature (after removal of the skin and fascia). B Mandibular and hyoid musculature. C-E Hyoid musculature. Abbreviations: AP M. dms, aponeurosis of muscle depressor mandibulae superficialis; bbc, Os basibranchiale caudale; M.bc, M. biventer cervicis; M. bm, M. brachiomandibularis; M. c, M. complex; M. cg, M. ceratoglosus; M. ch, M. cricohyoideus; M.dmsı, M. depressor mandibulae superficialis|ateral part; M.dms $s_{m}$ M. depressor mandibulae superficialismedial part; eb.ll, Os epibranchiale Il; M.g, M. genioglossus; M.ho, M. hypoglosus obliquus; M.hrc, M. hypoglosus rostralis cranialis; M.hrca, M. hypoglosus rostralis caudalis; M. ib, M. interceratobranchialis origin; M. id, M. intermandibularis dorsalis; M. iv, M. intermandibularis ventralis; M. rcl, M. rectus capitis lateralis; M. rcv , M. rectus capitis ventralislateralis parti M. sph, M. serpihyoideus; M. sth, M. sternohyoideus; M. styh, M. stylohyoideus; M. trh, M. trachiohyoideus

extend from the mandibular ramus to the Os ceratobranchiale and Os epibranchiale I. This muscle can be divisible into two heads, the cranial (internus) and caudal (externus) according to the attachment on the mandibular ramus, and both heads are divisible by a thin fascia. The caudal head is smaller (1.5-mm width) than the cranial (4-mm width) head of the muscle.

Both heads of the muscle originate with fleshy wide fibers from the inner surface of the mandibula at level from Os supra-angulare and Os pre-articulare. The caudal head origins more caudal region of Os prearticulare, while the cranial head has a wide origin from the inner surface of the mandibula at level Os supra-angulare. This muscle is inserted over the end of the Os ceratobranchiale and Os epibranchiale I, and very few fibers over the Os epibranchiale II also. It is innervated by a branch of the N. hypoglossus (12th nerve).

Comparison (Appendices 1 and 2)

The entire belly is $27-\mathrm{mm}$ long and $3-\mathrm{mm}$ broad and gets inserted with 12-mm-wide fleshy fibers. The caudal head is smaller than the cranial head of the muscle.

\section{Action}

Its bilateral contraction helps the lingua in protraction.

\section{Muscles associated with the apparatus hyomandibularis} M. interceratobranchialis (M. ib, Fig. 3B, C, Appendices 1 and 2)

The fleshy flap-like parallel fiber belly is situated underneath the $\mathrm{M}$. intermandibularis dorsalis. It conceals the proximal $\mathrm{M}$. trachiohyoideus and distal belly of the M. hypoglossus rostralis caudalis. An 11-mm-long muscle belly extends from the Os ceratobranchiale to the middle line of the Os basibranchiale caudale. It originates fleshly from the ventral side of the Os basibranchiale caudale. Both the parts arise from the mid-ventral line (i.e., 4-mm broad), and fibers run backward and outward. It inserts fleshly onto ventro-medial side of the Os ceratobranchiale just caudal and opposite to the insertion of the M. ceratoglossus and cranial to the insertion of the M. branchiomandibularis. It is innervated by a N. mandibularis of the $\mathrm{N}$. trigeminalis.

Comparison (Appendices 1 and 2)

The 11-mm-long muscle is fleshy and well developed in comparison.

\section{Action}

The muscle pulls the Os ceratobranchiale inward to raise the lingua when it bilaterally contracts.

M. ceratoglossus (M. cg, Fig. 3B-D, Appendices 1 and 2)

The parallel fiber belly is muscular, slender, and 11$\mathrm{mm}$ long extending between cranial outer margin of the Os entoglossum and Os ceratobranchiale. The 7-mm broad fleshy fibers arise from the lateral side of the cranial one half Os ceratobranchiale. All parallel fibers run forward and they converge in an aponeurosis sheath and finally turn into a 4-mm-long strong tendon, which runs over Mm. hypoglossus obliquus et rostralis. An aponeurosis long tendon inserts on the lateral side of the Os entoglossum. It is innervated by the $\mathrm{N}$. hypoglossus (12th nerve).

Comparison (Appendices 1 and 2)

The 7-mm-long parallel fibers get inserted by a 4-mmlong strong aponeurosis tendon. The 8-mm broad fleshy fibers arise from the lateral side of the cranial one half Os ceratobranchiale.

\section{Action}

This muscle acts as a depressor of the lingua.

M. hypoglossus (M. hr et ho, Fig. 3C, D, Appendices 1 and 2)

This muscle is covering the ventral surface of the Os entoglossum, cornuae of Os entoglossum, Os basibranchiale rostrale, and proximal Os basibranchiale caudale. It can be divided into two main parts, i.e., rostralis and obliquus, which are innervated by the N. hypoglossus.

a) M. hypoglossus rostralis (M. hr, Fig. 3C, D, Appendices 1 and 2)

It is situated on the ventral surface of the Os entoglossum, Os basibranchiale rostrale, and proximal Os basibranchiale caudale. According to its location, bellies are divided into two parts: (i) cranialis and (ii) caudalis.

(i) M. hypoglossus rostralis cranialis (M. hrc): The 6-mm-long parallel fleshy fibers arise from the cranio-lateral side of the Os basibranchiale rostrale just cranial to the origin of the M. hypoglossus obliquus. The whole sheet appears as an arrow shape thin layer and a little longer than caudalis part. All the fibers run medial and slightly forward converge 
on the middle line and finally merge with aponeurosis insertion of the M. ceratoglossus on the level of the tip of the Os entoglossum.

(ii) $\mathbf{M}$. hypoglossus rostralis caudalis (M. hrca): The 5-mm-long parallel fibers originate flashily from the latero-ventral surface of the Os basibranchiale rostrale just caudal margin of the M. hypoglossus obliquus. The entire sheet covers the junction of the Os ceratobranchiale and proximal latero-ventral surface of the Os basibranchiale caudale. All the parallel fibers run backward and fans out; finally, it merges flashily by fascia over the M. trachiohyoideus.

\section{Comparison (Appendices 1 and 2)}

It is similar from origin to insertion those of $S$. decaocto.

M. hypoglossus obliquus (M. ho, Fig. 3C, D, Appendices 1 and 2)

Very short subrectangular, 2-mm-long belly lies on the ventral surface of cornuae of the Os entoglossum and Os basibranchiale rostrale. A strong an aponeurotic tendon of the M. ceratoglossus passes over the lateral surface of this muscle. Both the counterparts originate flashily from the mid-ventral line (i.e., $1.5 \mathrm{~mm}$ ) of the Os basibranchiale rostrale dorsal to the insertion of the $\mathrm{M}$. stylohyoideus and M. cricohyoideus. All the fibers run outward and forward and finally insert flashily onto the ventral surface of cornuae of the Os entoglossum.

Comparison (Appendices 1 and 2)

No marked variation.

\section{Action}

Both the parts serve as a strong depressor of the lingua.

M. cricohyoideus (M. ch, Fig. 3D, E, Appendices 1 and 2)

A very small $1.6-\mathrm{mm}$-long parallel fiber belly roughly triangular lies in the deepest layer at the angle formed between the Os basibranchiale caudale and Os ceratobranchiale. The belly extends between the ventral and ventro-lateral surface of the cricohyoideus cartilage to the lateral surface of the Os basibranchiale rostrale. It arise fleshy from caudo-ventral and ventro-lateral margin of the cricoid cartilage and inserts fleshly onto dorsal surface of the cranial one fourth Os ceratobranchiale. Intermandibularis branch of the N. mandibularis of the $\mathrm{N}$. trigeminalis innervates this muscle.

Comparison (Appendices 1 and 2)

There is no marked variation.

\section{Action}

When it contracts, the muscle helps in the depression of the lingua.

M. sternohyoideus (M. sth, Fig. 3A-E, Appendices 1 and 2)

It is a thin ribbon-like muscle lying on the ventral surface of the trachea, immediately lateral to the mid-line and ventro-medial margin of the cricoid cartilage.
Dubale and Rawal (1966) agree this muscle as externus fasciculus part of M. rectus cervicis for C. livia, an innervation of the $\mathrm{N}$. hypoglossus cervicalis.

In all the specimens, the origin was caudal to the cut by which the head was detached from the body in preparation for dissection. All the parallel fibers were inserted flashily in the mid-ventral edge of the posterior rim of the cricoid cartilage sides, and counterparts of both sides are separated by a fascia.

Comparison (Appendices 1 and 2)

There is no marked variation.

\section{Action}

The contraction of this muscle depresses the cricoid cartilage along with it and also depresses the lingua.

M. trachiohyoideus (M. trh, Fig. 3A-D, Appendices 1 and 2)

This muscle is thin and long running along the dorsal to the lateral side of the trachea and remains attached to it. This muscle belly extends up to cricoid cartilage. Dubale and Rawal (1966) agree this muscles as internus fasciculus part of M. rectus cervicis for C. livia. It is innervated by the $\mathrm{N}$. hypoglossus (12th nerve).

In all the specimens, the origin was caudal to the cut by which the head was detached from the body in preparation for dissection. It was inserted flashily onto the caudo-dorsolateral margin of the cricoid cartilage.

Comparison (Appendices 1 and 2)

There is no marked variation.

\section{Action}

Bilateral contraction of the muscle aids in retracting the lingua by pulling near the cricoid cartilage. It also retracts the cranial portion of the trachea. The muscle also helps in the depression of the tongue.

Morphometrical data of the lingual muscles are summarized in Appendix 1.

\section{Diversity of food and food habits of the doves}

Doves are the terrestrial birds, resident, and locally nomadic depending upon food supply, and both the species are mainly grainy and seed eaters.

\section{Eurasian collared dove (S. decaocto)}

They feed mainly on plant matter such as grains, paddy, wheat, millet, jowar (Sorghum sp.), and other cereals and pulses at several microhabitats. They also eat some berries and green parts of the plants, as well as invertebrates (http://www.allaboutbirds.org/guide/EurasianCollared-Dove/ lifehistory). Several size seeds like the seeds of "vevadi" (Cocculus villosus) plant, seeds of sesame (Trivedi, 2012; Trivedi and Soni, 2013), and unusual feeding habits such as licking salty earthen pot (Trivedi, 2012; Trivedi and Soni, 2013) support the record of Van Tyne and Berger (1976); feeding on roasted gram and "Ganthia" (a fried item of gram-flour) are reported by 
Hathi et al. (2004), and they also feed on insects depending on the availability of food in the monsoon (Rana, 1991). As gut content examination recorded by Trivedi, (2012), Trivedi and Soni, (2013); which reports various grass seeds and grains such as grass seed of Seteria glauca, Seteria tomentosa, a seed of Tragus rouxburghii and seed of mustard and grit, supports the record of Mason and Maxwell-Lefroy (1912) stated that the Indian ring dove very often feeds on seeds of mustard, linseed, and lentil's grass and weed-seeds.

\section{Laughing dove (S. senegalensis)}

They usually forage on the ground in grasslands and cultivated areas. They mainly feed on plant matter as grass, fallen seeds, grains, and small fruit, bulbs, and other vegetation and small ground insects (such as termites and beetles), especially favor termites (http://www.avibirds.com/ $\mathrm{html}$ /Laughing_Dove. html). The food items have been recorded in its diet such as seed of grasses (genus: Eleusine, Panicum, Poa, Setaria, Urochloa), sedges (genus: Cyperus, Carex), trees and shrubs (genus: Atriplex, Amaranthus, Chenopodium, Cleome, Commelina, Croton, Cucumis, Hibiscus, Malva, Osteospermum, Oxalis, Physalis, Rhus, Solanum, Sphalmanthus, Talinum, Tetragonia, Ulmus, Acacia cyclops, Acacia saligna etc.), crushed seeds by passing traffics (Eucalyptus camaldulensis and Ficus natalensis), fruits such as Atriplex semibaccata, Ficus sycamore, Rhus, Salvadora persica, Flueggea virosa, nectar of Aloe marlothii, bulbs of sedges, and invertebrates such as termites, ants, house fly, larvae and pupa, snails etc. (http://www.biodiversityexplorer.org/birds/columbidae/Streptopeliasenegalensis. htm). Mason and Maxwell-Lefryoy (1912) recorded wheat, barley and paddy grains, seeds of mustard, linseed, and various weeds, "Toria" at time of threshing by Afzalhusain and Bhalla (1937) cited by Ali and Ripley (1983). While the stomach and esophagus examination report seeds of sesame (till) and seeds of a pumpkin or toria and grit (Trivedi, 2012; Trivedi and Soni, 2013), unusual feeding on roasted gram and "Ganthia" is also consumed offered by the human beings (Hathi et al., 2004).

\section{Discussion}

Eurasian collared dove and laughing dove are primarily feeding on plant matter, i.e., grains and seeds pecked from the ground. They do not require any massive or elongated bill for pecking and grasping their food grain. They feed on the variable size of seed and grains and depending on the availability of food and feed in adverse condition feed on the animal matter also.

\section{Muscular spiny lingua}

The lingua in Eurasian collared dove (Streptopelia decaocto) and laughing dove (Stigmatopelia senegalensis) studied here does not exhibit any wide variations in appearance as such. The dorso-ventrally concave to convex, slimy lingua has a pointed tip, broad at caudal, and caudal margin provides two long, thick backwardly directed lateral muscular smooth papillae linguales with several small central spines, which slightly differs in count in both dove species but such epidermal features help in picking up the food along bill epidermal and backwardly directed papillae linguales prevent the food materials entering in forwards direction. The area between lingua and glottis is comparatively long in Eurasian collared dove than laughing dove; and it has wide, elevated soft surface bear more or less small uniform size few scattered taste pits. Lateral of the glottis triangle mons-laryngealis shows comparatively fewer taste pits, and its caudal margins bear backwardly directed to the smooth lateral papillae. Folded frenulum linguae form a broad base caudally. These palpal folds and spiny epidermal features of buccal region provide good storage and transportation of food towards the esophagus. There was a little structural variation in the proportions of the lingua which is almost greater in Eurasian collared dove than in laughing dove and in sex also. These structural epidermal similarities in both dove species reveal similar food and feeding habits, but their variation may reflect their diverse macro- and micro-habitat use and feeding on diverse food habits. As in Eurasian collared dove, the gap between the lingua and glottis is longer than the laughing dove. This soft, elevated flashy surface is provided with numerous various sizes in an orderly arranged taste pits. It is suggested that the presence of various types of numerous taste pits is an adaptation to the omnivorous diet by Dubale and Thomas (1978). Eurasian collared dove feeds on plant matter as well as animal matter also and feed on insects (Rana, 1991). As in laughing dove, the area between the lingua and glottis is wide and soft; few taste pits are scattered irregularly and may support diverse plant matter choices. The lingua rotates the food matter in the buccal region with its epidermal adaptive features, which consider an adaptation of the lingua for swallowing (Gardener, 1926). The shape of the tongue of the birds is a species-specific trait and closely fits the shape of the lower part of the bill with a white-tailed eagle (Jackowiak and Godynicki, 2005).

\section{Lingual skeleton}

In both doves, the apparatus hyobranchialis and their skeleton elements are almost similar structurally, whereas the length of the Os epibranchiale I and II is a little longer in the $S$. senegalensis than in the $S$. 
decaocto. Eurasian collared dove bears a comparatively a little longer lingua since the apparatus hyobranchialis is the skeleton of a lingua. These may help actively in food handling and supports the lingua. More or less, their cartilaginous and bony skeleton may afford flexibility in lingual movements; besides, these provide a surface for the mandibular and lingual musculatures. The cornua of the Os entoglossum (= paraglosum) supporting the floor of the mouth serve for the attachment of a number of the jaw and lingual muscles (Rawal, 1966; Fatma, 2017). The apparatus hyobranchialis and their skeleton elements are almost similar but well developed in the rock dovePatagioenas livia (Fatma, 2017) and in Columba livia (Jones et al., 2019; Bhattacharyya, 1994) than in both dove species.

\section{Lingual musculature}

The birds are not in a position to use their lingua like the mammals due to the absence of the intrinsic lingual muscles and the particular nature of apparatus hyobranchialis, so they have to rely upon the movements of the entire lingua on its caudally placed attachment on the buccal floor. The movements of the lingua brought about by the large number of the muscles are as follows:

\section{Muscles operating the lingua}

The main function of the lingua in birds involves guiding of food in a proper direction and its transport towards the gullet. Various movements of the lingua during the feeding operation are the levation, depression, protraction, and retraction.

The fiber patterns of the lingual muscles show a rather parallel than pinnateness, flashy origin, and insertion in both doves.

Fleshy origin and insertion of the M. intermandibularis ventralis et dorsalis cover most of the medial surface of Os dentale. These elevate the buccal floor and follows tongue to lift up at their base; help the birds to press the food material against palate in the process of orientation of food before its transport towards the gullet.

\section{Depressors of the lingua}

M. hypoglossus rostralis et obliquus and ceratoglosus bring the depression of the lingua by their contraction. These muscles are well developed in both doves. Unilateral contraction depresses the lingua at the lateral side which helps the bird in collecting food.

\section{Levators of the lingua}

The raise of the lingua is brought about by the $\mathrm{Mm}$. interceratobranchialis, stylohyoideus and cricohyoideus.
These are strap-like muscles with parallel fibers. These muscles are well developed and their high degree of development reflects the ability for more effective lift of the lingua. As stated by Goodman and Fisher (1962), the muscles which are responsible for increasing of the buccal floor also simultaneously bring about the levation of the tongue. The M. tracheohyoideus and M. sternohyoideus also help in levation of the lingua. Among levators, the muscle $M$. interceratobranchialis is absent in the Demoiselle Crane (family: Gruidae) but present in Indian Black Ibis family: Threskiornithidae (Shukla, 1999).

\section{Protractors of the lingua}

Protractors of the lingua are brought about by a single muscle, the M. branchio-mandibularis. It is a very strong and well-developed muscle and also helps in sideway movement for a quick collection of the food. Well-developed M. genioglossus also helps in the movement of the lingua upward. It is fairly short with a measurement but massive and better developed in $S$. decaocto. Among protractors, the M. genioglossus muscle is absent in the Demoiselle Crane (family: Gruidae) but present in Indian Black Ibis family: Threskiornithidae (Shukla, 1999), absent in family Phasianidae (Soni, 1976) and in duck family: Anatidae (Yumnam, 2005).

\section{Retractors of the lingua}

This movement is brought about by the M. stylohyoideus which originates from the Os articulare and inserts on the anterior surface of Os basibranchiale rostrale. By its contraction, it causes pulling out of the lingua. It also abducts the lower jaw.

\section{Conclusion}

The lingua in Eurasian collared dove (Streptopelia decaocto) and laughing dove (Stigmatopelia senegalensis) studied here does not exhibit any wide variations in appearance as such. The eco-morphology studies of the lingual apparatus and all the associated components for feeding mechanism involve guiding of food in a proper direction and its transport towards the gullet. Various movements of the lingual musculature during the feeding operation are levators, depressors, protractors, and retractors which are suited to their food size and feeding habits as seed and grain feeding. Although the comparison between the two dove species is reflected, a relation in diverse food habits and all the morphological variables do not reflect allometric consequences of selection on body size. Finally, the assumption appears intuitively right between morphology, food habits, and variable size of the food items which clears various microhabitat choices in adverse conditions. 


\section{Appendix 1}

\section{Morphometrical data of lingual musculatures}

(The mid-line mean value in millimeter for the length and width of UF1 specimens for both species)

\begin{tabular}{|c|c|c|c|c|c|c|c|c|c|c|c|c|}
\hline \multirow[t]{2}{*}{ Muscle } & \multicolumn{6}{|c|}{ Eurasian collared dove } & \multicolumn{6}{|c|}{ Laughing dove } \\
\hline & $\mathrm{L}(\mathrm{mm})$ & LET $(\mathrm{mm})$ & Total $(\mathrm{mm})$ & $\mathrm{W}(\mathrm{mm})$ & WFF (mm) & $\overline{M(m g)}$ & $\overline{L(m m)}$ & LET $(\mathrm{mm})$ & Total $(\mathrm{mm})$ & $\mathrm{W}(\mathrm{mm})$ & WFF (mm) & $M(\mathrm{mg})$ \\
\hline M.iv & 3.0 & 00 & 3.0 & 17.0 & $\begin{array}{l}16.0 \\
16.0\end{array}$ & - & 2.5 & 00 & 2.5 & 18.0 & $\begin{array}{l}\mathbf{1 7 . 0} \\
17.0\end{array}$ & - \\
\hline M.id & 14.0 & 00 & 14.0 & 3.0 & $\begin{array}{l}\mathbf{2 . 5} \\
5.0\end{array}$ & - & 12.0 & 00 & 12.0 & 2.0 & 4.0 & 4.0 \\
\hline M.styh & 12.5 & 00 & 12.5 & 1.5 & $\begin{array}{l}\mathbf{2 . 0} \\
0.5\end{array}$ & - & 18.0. & 00 & 18.0 & 1.5 & - & 2.7 \\
\hline M.sph & 18.0 & 00 & 18.0 & 1.0 & 2.0 & - & 25.0 & 00 & 25.0 & 1.5 & - & 8.6 \\
\hline M.g & 13.0 & 00 & 13.0 & 3.0 & - & - & 18.0 & 00 & 18.0 & 3.0 & - & - \\
\hline M.bm & 23.5 & 00 & 23.5 & 5.0 & 5.5 & 16.5 & 27.0 & 00 & 27.0 & 3.0 & 12.0 & 9.4 \\
\hline M.ib & 11.0 & 00 & 11.0 & 1.0 & 4.0 & 1.9 & 11.0 & 00 & 11.0 & 2.0 & 3.0 & 1.1 \\
\hline M.cg & 7.0 & 4.0 & 11.0 & 1.0 & 7.0 & 1.6 & 7.0 & 4.0 & 11.0 & - & 8.0 & 0.8 \\
\hline $\mathrm{M} \cdot \mathrm{hr} \mathrm{cr}_{\mathrm{cr}}$ & 6.0 & 00 & 6.0 & 1.0 & - & - & 6.0 & 00 & 6.0 & 1.0 & - & - \\
\hline $\mathrm{M} \cdot \mathrm{hr}_{\mathrm{ca}}$ & 5.0 & 00 & 5.0 & 1.2 & - & 1.6 & 5.0 & 00 & 5.0 & 1.2 & - & - \\
\hline M.ho & 2.0 & 00 & 2.0 & 2.0 & $\begin{array}{l}1.5 \\
2.0\end{array}$ & 0.1 & 2.0 & 00 & 2.0 & 2.0 & $\begin{array}{l}1.5 \\
2.0\end{array}$ & - \\
\hline
\end{tabular}

M.ch $\quad 1.6 \quad 00 \quad 1.6$

$1.6 \quad 00 \quad 1.6$

Bold numerical represents tendon for the origin and regular for the insertion in WFF. Other abbreviations are the same used for the lingual muscles in Fig. $3 \mathrm{~A}-\mathrm{E}$ Abbreviations: L length, W width, WFF width of fleshy fibers, LET length of external tendon, M mass (- denotes not possible to measure in a mass column)

\section{Appendix 2}

Comparison of fiber patterns, origin, and insertion of lingual muscles

\begin{tabular}{|c|c|c|c|c|c|c|}
\hline \multirow[t]{2}{*}{ Muscle } & \multicolumn{3}{|l|}{ Streptopelia decaocto } & \multicolumn{3}{|c|}{ Stigmatopelia senegalensis } \\
\hline & Fiber patterns & Origin by & Insertion by & $\begin{array}{l}\text { Fiber } \\
\text { patterns }\end{array}$ & Origin by & $\begin{array}{l}\text { Insertion } \\
\text { by }\end{array}$ \\
\hline M.iv & Parallel origin and insertion & $\begin{array}{l}\text { Extensive fleshy } \\
\text { fibers }\end{array}$ & Extensive fleshy fibers & - & - & - \\
\hline M.id & Parallel origin and insertion & Fleshy fibers & Broad fleshy fibers & - & - & - \\
\hline M.styh & Parallel origin and insertion & Fleshy fibers & Fleshy fibers & - & - & - \\
\hline M.sph & Pinnate Parallel origin & Fleshy fibers & Fleshy fibers & - & - & - \\
\hline M.g & $\begin{array}{l}\text { Pinnate Parallel origin and } \\
\text { insertion }\end{array}$ & Broad fleshy fibers & Broad fleshy fibers & - & - & - \\
\hline M.bm & Pinnate Parallel origin & Broad fleshy fibers & Extensive fleshy fibers & - & Fleshy fibers & - \\
\hline M.ib & $\begin{array}{l}\text { Pinnate Parallel origin and } \\
\text { insertion }\end{array}$ & Broad fleshy fibers & Narrow fleshy fibers & - & Fleshy fibers & - \\
\hline M.cg & Parallel pinnate origin & $\begin{array}{l}\text { Extensive fleshy } \\
\text { fibers }\end{array}$ & Long aponeurosis tendon & - & $\begin{array}{l}\text { Extensive fleshy } \\
\text { fibers }\end{array}$ & - \\
\hline M.hr $r_{\mathrm{cr}}$ & Pinnate Parallel origin & Fleshy fibers & $\begin{array}{l}\text { Fleshy fibers merge in } \\
\text { aponeurosis }\end{array}$ & - & - & - \\
\hline M.hr $r_{c a}$ & Pinnate Parallel origin & Fleshy fibers & Fleshy fibers merge in facia & - & - & - \\
\hline M.ho & $\begin{array}{l}\text { Parallel origin and pinnate } \\
\text { insertion }\end{array}$ & Fleshy fibers & Fleshy fibers & - & - & - \\
\hline M.ch & Pinnate origin & Fleshy fibers & Fleshy fibers & - & - & - \\
\hline M.sth & Parallel pinnate origin & Broad fleshy fibers & Fleshy fibers & - & - & - \\
\hline M.trh & Parallel pinnate origin & Broad fleshy fibers & Narrow fleshy fibers & - & - & - \\
\hline
\end{tabular}

-Denotes similar description, fleshy fibers indicate the width is = or $>3 \mathrm{~mm}$, broad fleshy fibers' width is $<3 \mathrm{~mm}$, extensive fleshy fibers' width is $<7 \mathrm{~mm}$, similar consideration for the length of the aponeurosis tendon as short, long, and longer 


\section{Acknowledgements}

I am thankful to my respected mentor Retired Prof. V. C. Soni. I would like to thank the Retired Prof \& Principal Dr. M. I. Patel for his suggestion on the manuscript of this paper and to the Head \& Prof. S. P. Singh, Department of Biosciences, Saurashtra University, Rajkot, for providing the necessary laboratory facility.

\section{Author's details}

'UGC-CAS Department of Biosciences|UGC Centre of Advanced Studies Saurashtra University, Rajkot 360005|Gujarat State||ndia Cell: +919879077309;

E-mail: vtrivedi_2@rediffmail.com (Primary); vmtrivedi@sauuni.ac.in (Alternate mail (d-1)

Web: http://www.saurashtrauniversity.edu|Orcid Id:0000-0001-95416532|Researcher Id: Q-9331-2018

Research Gate Link: https://www.researchgate.net/profile/Varsha_Trivedi2

Vidwan Database Link: https://vidwan.inflibnet.ac.in/profile/69019

\section{Funding}

University Grants Commission (UGC), Govt. of India, New Delhi, for supporting this study as a part of departmental research through its DSA Centre of Advanced Study Programme (CAS).

\section{Availability of data and materials}

No dataset was analyzed in the current study.

Author's contributions

The final manuscript was read and approved by the author.

\section{Ethics approval and consent to participate}

The author declares that this work is carried out within an appropriate ethical framework.

\section{Consent for publication}

Not applicable.

\section{Competing interests}

The author declares that she has no competing interests.

\section{Received: 4 June 2019 Accepted: 25 February 2020}

Published online: 22 June 2020

\section{References}

Ali, S., \& Ripley, S. D. (1983). Handbook of the birds of India and Pakistan Vol. I. Oxford, New York: Compact edition, Oxford University Press (citation of Afzalhusain and Bhalla 1937).

Baumel, J. J., King, A. S., Lucas, A. M., Breazile, J. E. and Evans, H. E. (1979). Nomina Anatomica Avium. US edi. Academic Press Inc., New York 1-637.

Baumel, J. J., King, A. S., Lucas, A. M., Breazile, J. E., Evans, H. E., \& Vanden Berge, J. C. (1993). Hand book of avian anatomy. Nomina Anatomica Avium II. Publ 23, (pp. 1-779). Cambridge: Massachusetts: The Nuttall Ornithological Club Publication.

Bhattacharyya, B. N. (1994). Diversity of feeding adaptations in certain columbid birds: A functional morphological approach. Journal Bioscience, 19(4), 415427.

Bock, W. J. (1972). Morphology of the tongue apparatus of Ciridops anna (Drepanididae). Ibis, 114, 61-78.

Bock, W. J. (1978). Tongue morphology and affinities of the Hawaiian Honeycreeper Melamprosops phaeosoma. Ibis, 120(4), 467-479.

Dubale, M. S. and Rawal, U. M. (1966). The jaw muscles of Columba livia intermedia Strickland. Proceeding $2^{\text {nd }}$ All Indian Congress. Zoology, Varanasi (1962), 2: 248-255.

Dubale, M. S., \& Thomas, V. C. (1978). The epidermal structures of the tongue and the buccal cavity of the Brahminy Myna (Sturnus pagodarum Gmelin) and the Wagtail (Motacilla flava thunbergi Billberg). Acta Zoologica (Stockh), 59, 149-155.

Engel, W. L. (1938). Tongue musculature of passerine birds. Auk, 55, 642-650.

Fatma, A., \& Al-Nefeiy (2017). Kinetics of the Hyoid Skeleton of the Rock Dove (Patagioenas livia). International Journal of Advanced Research in Biological Sciences, 4(10), 51-61. https://doi.org/10.22192/ijarbs.2017.04.10.009.
Gardener, L. L. (1926). The adaptive modifications and the taxonomic value of the tongue in birds. From the Proceedings of the United States National Museum $67,1-49$

Goodman, D. C., \& Fisher, H. I. (1962). Functional anatomy of the feeding apparatus in waterfowl, (Aves: Anatidae), (pp. 1-193). USA: Southern Illinois Univ Press https:/www.Amazon.Com/Function al-Anatomy-Feeding-ApparatusWaterfowl/dp/0809300664.

Grimmett, R., Inskipp, C. and Inskipp, T. (2014). Field Guides: Birds of the Indian Subcontinent, Oxf. Uni. Press. https://www.amazon.in/Birds-IndianSubcontinent-Carol-Inskipp/dp/019807722X

Hathi, D., Jhala, R. and Trivedi, B. (2004). Unusual feeding behaviour of River Tern (Sterna aurantia). Flamingo, BCSG, Gujarat; Vol. 2, 3 \& 4, 1-12. http:// indianbirds.in/pdfs/B.6.4-5.pdf

Homberger, D. G., \& Meyers, R. A. (1989). Morphology of the lingual apparatus of the domestic chicken, Gallus gallus, with special attention to the structure of the fascia. American Journal of Anatomy, 186(3), 217-257.

Jackowiak, H., \& Godynicki, S. (2005). Light and scanning electron microscopic study of the tongue in the white tailed eagle (Haliaeetus albicilla, Accipitiridae, Aves). Annals of Anatomy, 187, 251-259.

Jackowiak, H., \& Ludwig, M. (2008). Light and scanning electron microscopic study of the structure of the ostrich (Strutio camelus) tongue. Zoological Science, 25, 188-194.

Johnson, K. P., Kort, S. D., Dinwoodey, K., Mateman, A. C., Cate, C. T., Lessells, C. M. \& Clayton, D. H. (2001). A molecular phylogeny of the dove genera Streptopelia and Columba. The Auk, 118(4), 874-887.

Jones, M. E. H., Button, D. J., Barrett, P. M., \& Porro, L. B. (2019). Digital dissection of the head of the rock dove (Columba livia) using contrast enhanced computed tomography. Zoological Letters, 5, 17. https://doi.org/10.1186/ s40851-019-0129-z.

Lucas, A. M. and Stettenheim, P. R. (1972). Avian anatomy. Integument. Part I, Agriculture Handbook 362, U.S. Dept. Agric., Washington, D.C.

Mahmoud, F. A., Gadel-Rab, A. G., \& Shawki, N. A. (2018). Functional morphological study of the choana in different bird species. The Journal of Basic and Applied Zoology, 3-9. https://doi.org/10.1186/s41936-018-0026-6.

Mason, C. W. and Maxwell-Lefroy, H. (1912). The food of birds in India, Mem Dep Agriculture India. Ento Ser. 3 (pusa), 232-233.

McLelland, J. (1968). The hyoid muscles of Gallus gallus. Acta anat, 69, 81-86.

Morioka, H. (1974). Jaw musculature of Swifts, (Aves-Apodidae). Bulletin of National Science Museum, 17(1), 1-16 http://docplayer.net/148111854Bulletin-of-the-british-ornithologists-club.html.

Mudge, G. P. (1903). On the myology of the tongue of parrots, with a classification of the order based upon the structure of tongue. The Transactions of the Zoological Society of London, 16, 211-278.

Rana, B. D. (1991). Ecology of the Indian Ring Dove in an arid environment. International Symposium On Environmental and Hormonal approaches to Ornithology. Garwhal Univ. Srinagar, UP (Abstract).

Rawal, U. M. (1966). Certain aspect of the functional anatomy of the feeding apparatus in some Picarian group of birds. Doctoral Thesis: Gujarat University, Ahmedabad.

Rawal, U. M. (1970). A Comparative account of the lingual myology of some birds. Proc. Indian Acad. Sci., LXXI (1), Sect. A.: 36-46.

Shawki, N. A., Abdeen, A. M. and Mahmoud, F. A. (2016). FunctionalMorphological Study of the Oropharyngeal Cavity and the Tongue of the Common Kestrel, (Falco Tinnunuculus) Part I: The Roof of the Oropharyngeal Cavity International Journal of Research Studies in Zoology (IJRSZ), 1(3): 16-26.

Shawki, N. A., \& Al-Jalaud, N. A. (1994). sss. The Egyptian Journal of Anatomy, 17(4), $51-78$.

Shukla, M. (1999). Feeding adaptations in some birds with special reference to groundnut feeding habit in Saurashtra. Rajkot, India: Doctoral Thesis, Saurshtra University http://etheses.Saurashtrauniversity.edu.

Soni, V. C. (1976). Feeding and locomotor adaptations in birds: Family Phasianidae. Ahmedabad, India: Doctoral Thesis, Gujarat University.

Tivane, C., Rodrigues, M. N., Soley, J. T., \& Groenewald, H. B. (2011). Gross anatomical features of the oropharyngeal cavity of the ostrich (Struthio camelus). Pesquisa Veterinária Brasileira, 31, 543-550.

Trivedi, V., \& Soni, V. C. (2013). Epidermal Structures of the Bill and Lingua of the Eurasian Collared Dove (Streptopelia decaocto). Journal on New Biological Reports, 2(1), 44-54.

Trivedi, V. M. (2012). Feeding and locomotor adaptations in doves, (pp. 1-521). Rajkot, Gujarat, India: Doctoral Thesis, Saurashtra University http://etheses. Saurashtrauniversity.edu/954/1trivedivm thesisanimal\%20science.pdf. 
Van Tyne, J., \& Berger, A. J. (1976). Fundamentals of Ornithology. New York: Book, John Wiley and Sons.

Venkatesan, S., Shazia, N., Kannan, T. A., Sabiha, H. B., \& Geetha, R. (2015). Functional morphology of the epidermal structures of the feeding apparatus of Guinea fowl (Numidia meleagris). International Journal of Advanced Research, 3(10), 1601-1608 Journal homepage: http://www.journalijar.com.

Weymouth, R. D., Lasiewshi, R. C., \& Berger, A. J. (1964). The tongue apparatus in Humming birds. Acta Anatomica, 58, 252-270.

Yumnam, A. (2005). Locomotor and feeding adaptations in Birds (With reference to certain species of ducks). Rajkot, India: Doctoral Thesis, Saurashtra University.

Zweers, G. A. (1974). Structure, Movement and Myography of the Feeding Apparatus of the Mallard (Anas Platyrhynchos L.) a Study in Functional Anatomy In. Netherlands Journal of Zoology, 24(4), 323-467.

Zweers, G. A. (1982a). The feeding system of the pigeon (Columba livia L.). Advances in Anatomy, Embryology and Cell Biology, 73, 1-108 https://www. springer.com/gp/book/9783540113324

Zweers, G. A. (1982b). Pecking of the pigeon (Columba livia L.). Behaviour, 81(2/4), 173-230 (58 pages). https://www.jstor.org/stable/4534205.

\section{Publisher's Note}

Springer Nature remains neutral with regard to jurisdictional claims in published maps and institutional affiliations.

\section{Submit your manuscript to a SpringerOpen ${ }^{\circ}$ journal and benefit from:}

- Convenient online submission

- Rigorous peer review

- Open access: articles freely available online

- High visibility within the field

- Retaining the copyright to your article

Submit your next manuscript at $\boldsymbol{\nabla}$ springeropen.com 